\title{
BISNIS SEBAGAI GERAKAN DAKWAH DAN DAMPAKNYA BAGI KESEJAHTERAAN SOSIAL MENURUT TAFSIR AL-MISBAH
}

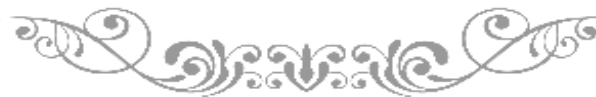 \\ Kris Nandang \\ IAIN Syekh Nurjati Cirebon \\ Email: krisnandang99@gmail.com \\ Suciyadi Ramdhani \\ IAIN Syekh Nurjati Cirebon \\ Email: suciyadiramdhani@gmail.com
}

\begin{abstract}
This paper aims to describe business in the view of Islam according to Ibn Ubaid in Kitab Al-Amwal. The focus studied is business as a da'wah movement that has an impact on the social welfare of the people as exemplified by the role model of Muslims, Prophet Muhammad SAW. Through literature review, data collection comes from books and articles and analyzed and triangulation of data. Through this method, it can be explained that Islam accommodates every human effort in managing his life through business. It is based on teachings that are attentive to social life so that an Islamic business culture is formed which leads to social welfare through three main assets as a guide, namely, profit (material) and benefit (non-material), growth and blessings. Quraish Shihab shows that Islam's attention to every business that contains benefits for others deserves appreciation in one's spiritual quality. In addition, economic stability and good governance of state administration are factors for creating prosperity by adhering to the principles of monotheism, the benefit of mankind, the unity of humanity, the belief in the unity of the world and the hereafter.
\end{abstract} Keywords: Quraish Shihab, Islamic Business, Social Welfare.

\footnotetext{
Abstrak

Tulisan ini bertujuan untuk mendeskripsikan bisnis dalam pandangan Islam menurut Quraish Shihab dalam Tafsir Al Mishbah. Fokus yang dikaji adalah bisnis sebagai gerakan dakwah yang berdampak pada kesejahteraan sosial umat seperti yang dicontohkan oleh Nabi Muhammad Saw. melalui kajian literatur,
} 
pengumpulan data bersumber dari buku dan artikel lalu dianalisa serta triangulasi sumber data. Melalui metode tersebut dapat dijelaskan bahwa Islam mengakomodasi setiap usaha manusia dalam menata hidupnya melalui bisnis. Dilandasi ajaran yang penuh perhatian terhadap kehidupan sosial sehingga terbentuk budaya bisnis Islam yang bermuara pada kesejahteraan sosial melalui tiga modal utama sebagai pegangan yaitu, profit (materi) dan benefit (non materi), pert umbuhan dan keberkahan. Pemikiran Muhammad Quraish Shihab dalam Tafsir Al-Misbah menunjukkan bahwa perhatian Islam pada setiap usaha yang mengandung manfaat bagi orang lain berhak mendapat apresiasi dalam kualitas spiritual seseorang. Selain itu, stabilitas ekonomi dan tata kelola administrasi negara yang baik menjadi faktor terciptanya kesejahteraan dengan memegang prinsip Tauhid, kemaslahatan umat manusia, kesatuan kemanusiaan, keyakinan akan kesatuan dunia dan akhirat.

Kata Kunci: Quraish Shihab, Bisnis Islami, Kesejahteraan Sosial

\section{PENDAHULUAN}

Islam merupakan agama yang mengatur praktik spiritual antara manusia dengan Tuhan (ibadah mahḍah). Di sisi lain, Islam juga mengatur kehidupan manusia hingga ke berbagai praktik kehidupan terutama dalam bermuamalah (ibadah ghairu maḥ̣ah). Sebagai agama wahyu yang diturunkan kepada Muhammad Saw. yang notabene adalah seorang manusia, Islam telah masuk pada pandangan hidup yang menunt un bagaimana manusia harus menjalani kehidupannya.

Oleh karena itu, Islam telah menjadi tunt unan hidup bagi umatnya dari setiap masalah yang hadir dalam kehidupan manusia karena Islam bukan sekedar penghambaan pada Tuhan dengan berbagai ritual keagamaan, namun lebih dari itu Islam meneguhkan prinsip-prinsip sosial kemanusiaan yang terpuji. Nilai ideal yang terkandung dalam menentukan umatnya yang terbaik adalah seseorang yang paling bermanfaat untuk umat dan seseorang yang mampu mengubah nasibnya sendiri ke arah lebih baik dengan senantiasa berikhtiar dalam beramal saleh dan bekerja sesuai dengan prinsip Islam. ${ }^{1}$

Pengertian di atas dapat dijelaskan bahwa Islam mewajibkan setiap Muslim, khususnya yang memiliki tanggungan untuk bekerja. Bekerja merupakan salah satu sebab pokok yang memungkinkan manusia memiliki harta kekayaan. Untuk memungkinkan manusia berusaha mencari nafkah, Allah Swt melapangkan bumi serta menyediakan berbagai fasilitas yang dapat

${ }^{1}$ M Elkarimah, "Etos Kerja Islami dalam Mewujudkan Kesejahteraan Sosial," AnNuha, Vol. 3 No.1 (Juni 2016): 100. 
dimanfaatkan untuk mencari rezeki. ${ }^{2}$ Sebagaimana dikatakan dalam firman Allah QS. al-Mulk ayat 15 :

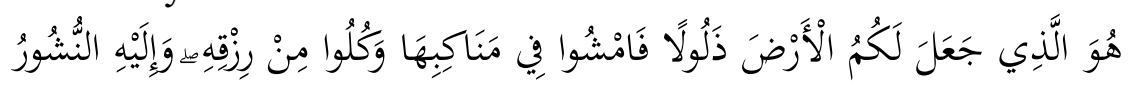

"Dialah Yang menjadikan bumi itu mudah bagi kamu, maka berjalanlah di segala penjurunya dan makanlah sebahagian dari rezeki-Nya. Dan hanya kepada-Nya-lah kamu (kembali setelah) dibangkitkan."

Salah satu perjuangan umat Islam yang telah terekam dalam sejarah adalah bagaimana Rasulallah Saw. dan umat terdahulu berjuang untuk agama dengan berusaha membangun pondasi yang kokoh di bidang ekonomi. Sejak dini, Rasul sudah terjun di dunia bisnis dengan berbekal kejujuran dan ketekunannya, hingga gelar terpuji "al-amin" disematkan sebagai penghormatan masyarakat atas keteladananya. Kemampuannya dalam mengelola bisnis, menjadikan Muhammad Saw. memiliki kekayaan terbanyak pada masa itu. Seorang ahli sejarah bernama Shayk al-Mufid [337-413 H] meriwayatkan bahwa pada usia sekitar 20 tahun kekayaan Muhamad adalah yang paling banyak, baik berupa emas permata, unta, kuda, karyawan, dan beberapa aset tanah di jazirah Makkah, ${ }^{3}$

Begitupun dengan para sahabatnya yang setelah memeluk Islam, banyak di kalangan mereka yang berprofesi sebagai pengusaha. Dari mulai ke empat Khulafä‘ al-Rāshidin bahkan dikatakan sembilan dari sepuluh alSäbiqūn al-Awwalūn itu adalah para saudagar, sehingga tidak heran bila Nabi menyatakan dalam sabdanya, "Sembilan dari sepuluh pintu rezeki adalah berniaga" (HR. Tirmidzi).

Namun, realitanya persepsi tersebut menimbulkan dinamika di kalangan umat Islam khususnya di Indonesia. Fenomena ketertinggalan dan kemunduran umat Islam, terutama dalam hal pembangunan ekonomi, sosial dan politik dihadapkan dengan perkembangan dunia Barat, misalnya Eropa dan Amerika yang diyakini memiliki perbedaan mendasar dari cara berpikir, ideologi dan paradigma yang dianut mereka sebagai cara pandang hidup (way of life). Max Weber pun mengungkapkan bahwa nilai-nilai yang terkandung dalam suatu agama atau budaya mempengaruhi perilaku para pemeluknya termasuk kehidupan perekonomiannya. ${ }^{4}$

2 Norvadewi, "Bisnis dalam Persfektif Islam (Telaah Konsep, Prinsip dan Landasan Normatif)," Al-Tijary, Vol. 01, No. 01 (Desember 2015): 36.

3 Tanjung, M Azrul dkk., Reinventing Budaya Bisnis untuk Kesejahteraan dan Kejayaan Peradaban Islam (Jakarta:Grafindo,2014), 67.

4 Zamroni, "Dinamika interkorelasi antara konsep Diri, Zuhud dan Motivasi berprestasi Santri.” (Conference (Paper), UIN Maulana Malik Ibrahim Malang, 2010), 2. 
Pendapat tersebut disandarkan pada prilaku sebagian umat Islam yang salah dalam memahami konsep zuhud. ${ }^{5}$ Hal senada juga diungkapkan oleh kelompok insiders (cendekiawan Muslim) dengan memberikan catatan dan penekanan bukan pada nilai-nilai ajaran agama Islam itu sendiri, namun lebih pada pemeluk agamanya yang salah menafsirkan pesan-pesan ajarannya.

Hamka mengkritik tasawuf yang sangat erat dengan zuhud menjadi penyebab terhambatnya perkembangan ajaran Islam. Tasawuf yang mengajarkan sikap zuhud seharusnya mampu menjadi motor penggerak kebangkitan umat Islam. Menurut Nurcholish Madjid, dunia tasawuf yang cenderung bersifat pasif dan isolatif, dalam kerangka neo-modernisme harus dirubah menjadi tasawuf yang aktif dan terbuka. ${ }^{6}$

Hal tersebut dianggap menurunkan etos kerja umat Islam, padahal bisnis adalah salah satu kesempatan manusia untuk beramal bagi kesejahteraan komunitas Muslim lainnya. Menurut Latief, akitivitas amal dan dakwah merupakan dua kegiatan yang tidak bisa dipisahkan. Aktivitasaktivitas amal yang dilakukan bukan hanya kewajiban spiritual umat melainkan juga mempengaruhi kehidupan komunitas Muslim. ${ }^{7}$

Dengan merosotnya perekonomian suatu bangsa tentu berdampak pada rendahnya kesejahteraan sosial pada negara tersebut. Padahal bisnis berpengaruh besar pada kehidupan ekonomi, sosial, bahkan politik umat serta kestabilannya sebagaimana menurut Hasyim Muzadi yang menjelaskan bahwa salah satu jalan yang bisa ditempuh untuk menggerakan laju pertumbuhan ekonomi nasional, sekaligus meningkatkan kesejahteraan dan kemakmuran rakyat adalah dengan pemberdayaan ekonomi yang berpijak pada tiga pilar. Pertama, pemberdayaan ekonomi di lembaga keagamaan. Kedua, pemberdayaan ekonomi masyarakat pedesaan, dan ketiga, pemberdayaan ekonomi perkotaan. ${ }^{8}$ Maka yang perlu diupayakan saat ini adalah cara untuk memberikan pengertian dan pemahaman yang benar mengenai watak esensial dari ajaran Islam terkait bisnis sebagai gerakan kemanusiaan yang memiliki dampak pada kesejahteraan sosial umat.

Kesejahteraan sosial yang menjadi nilai ideal dalam Islam sejatinya tidak hanya ditinjau dari segi terpenuhinya kebutuhan dasar jasmani seperti makan dan tempat tinggal, tapi juga termasuk kebutuhan rohani seperti ketenangan, kenyamanan, perlindungan, persamaan kedudukan dalam hukum

${ }^{5}$ Menurut Abū Ḥamīd Muhammad bin Muhammad al-Ghazali, Zuhud ialah suatu sikap tidak sukanya seseorang terhadap dunia lalu berpaling kepada akhirat atau tidak sukanya terhadap selain Allah lalu berpaling pada Allah (Skripsi, Ahmad Khunaefi).

6 Zamroni, "Dinamika interkorelasi antara konsep Diri, Zuhud dan Motivasi berprestasi Santri," 3.

${ }^{7}$ Latief, H, Islamic Charities and Social Activism (Utrecht University, 2012).

8 Tanjung, M Azrul dkk, Reinventing Budaya Bisnis untuk Kesejahteraan dan Kejayaan Peradaban Islam, 120. 
dan peradilan seperti yang dijelaskan M. Quraish Shihab dari intisari Tafsir al-Misbah dan karya-karyanya yang lain.

Tulisan ini merupakan kajian literatur, dengan pengumpulan data bersumber utama tafsir al-Misbah karya M. Quraish Shihab serta dari buku, kitab dan artikel yang berkaitan dengan bisnis dan kesejahteraan sosial dalam pandangan Islam. Setelah diperoleh data-data yang dibutuhkan, selanjutnya penulis mereduksi data ke dalam kategori-kategori yang berkaitan dengan topik yang disajikan dalam pembahasan seperti konsep bisnis dalam Islam, bisnis dan kesejahteraan sosial, serta dampak bisnis Islami di Indonesia.

\section{PEMBAHASAN}

\section{Bisnis dalam Islam}

Bisnis atau berniaga merupakan suatu istilah yang sangat umum diungkapkan dalam Islam yang biasanya dimanifestasikan dalam dunia perdagangan. Dari segi literatur kebahasaan, bisnis berasal dari Bahasa Inggris, yaitu: business yang artinya kesibukan. Bisnis adalah suatu kegiatan usaha invidu yang terorganisasi untuk menghasilkan dan menjual barang dan jasa guna mendapatkan keunt ungan dalam memenuhi kebutuhan masyarakat. ${ }^{9}$

Menurut Brown dan Pretello, pengertian bisnis adalah lembaga yang menghasilkan barang dan jasa yang dibutuhkan oleh masyarakat serta semua hal yang mencakup berbagai usaha yang dilakukan pemerintah maupun swasta tidak peduli mengejar laba atau tidak. Kemudian apabila disandingkan dengan istilah Islam yang berisi tata aturan moralitas penghambaan pada Tuhan Yang Esa dan terhadap alam semesta juga isinya, istilah bisnis akan mendapatkan pengertian yang berbeda. ${ }^{10}$

Bisnis dalam Islam mengandung makna yang menunjukan suatu praktik bersosial lewat pemanfaatan sumber daya dan mencari keuntungan berdasarkan prinsip prinsip yang Islami. Maka dari itu, tujuan dari bisnis yang dinaungi Islam bukan hanya sekadar perihal mencari rezeki tapi justru harus dijiwai oleh nilai spiritual, pengharapan akan keridaan dari sang Kuasa. Sehingga setiap anggapan yang miring umat Islam terhadap bisnis akan tertolak dengan sendirinya.

Islam secara alamiah tidak pernah menjadikan berbisnis sebagai suatu kegiatan yang harus dihindari, namun umat Islam dinilai kurang bijak dalam menentukan hal semacam ini. Satu narasi yang sederhana yang dikira tepat untuk masalah tersebut bahwa "Islam dan Muslim itu berbeda". Islam adalah bukti kemurnian dan kesucian namun Muslim punya peluang untuk tidak menyadari kemurnian Islam itu sendiri.

${ }^{9}$ Muhamamad Ardi, “Etika Bisnis dalam Ekonomi Islam,” Jurnal Syari'ah Vol. 3, No. 1 (April 2015): 35.

${ }^{10}$ Muhamamad Ardi, "Etika Bisnis dalam Ekonomi Islam”: 36. 
Padahal Islam sendiri menyadarkan manusia bahwa hidup yang lebih baik adalah kehidupan yang paling bermanfaat untuk banyak orang. Hidup yang mampu mentransformasikan diri, dari hidup yang kurang layak menjadi hidup yang layak. Maka al-Qur'an menegaskan bahwa Allah tidak akan mengubah nasib suatu kaum sebelum kaum itu sendiri mengubah keadaannya. Bahkan di ayat yang lain disebutkan, "tiada yang manusia peroleh selain dari apa yang ia usahakan" (QS. al-Najm: 39). Hal tersebut berarti manusia dimampukan Tuhan untuk bisa memperbaiki diri menjadi berdaulat.

Allah tidak menyukai orang orang yang berlebihan, hal tersebut sudah menjadi pemahaman bersama. Karena itu pula konsep menyederhanakan diri menjadi suatu sikap yang mulia, sikap itu biasa disebut sebagai zuhud ${ }^{11}$, tidak mengharapkam berlebih pada dunia dan berharap penuh pada kenikmatan di akhirat kelak.

Pandangan tersebut pada hakikatnya adalah hal mulia, namun jika dipahami dogma tersebut sebagai keutamaan bagi orang yang tidak mampu, maka terkait urusan 'menanam' amal manusia di dunia, Islam mendorong umat manusia untuk membayar zakat dan haji yang merupakaan bagian dari rukun Islam sebagai penyempurnaan atas keimanan dan ketaqwaan manusia. Dengan demikian, bagaimana seseorang dapat mengeluarkan zakat atau bahkan melaksanakan ibadah haji jika finansial seseorang itu tidak memadai. Artinya, Islam berupaya mendorong umatnya untuk memiliki perekonomian yang baik agar menjadikan ibadah lebih tertata dan kehidupannya lebih berguna bagi sesama, seperti kutipan ayat berikut:

- QS. al-Nabā: 10-11

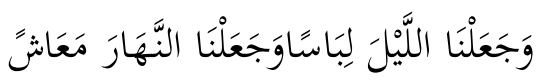

"Dan kami jadikan malam sebagai pakaian dan siang sebagai penghidupan"

- QS. al-Dhāriyāt: 58

$$
\text { إِنَّ اللَّهَ هُوَ الرَزَّاقُ ذُو الْقُوَّةٍ الْمَتِينُ }
$$

"Sesungguhnya Dialah Allah Maha pemberi rezeki yang mempunyai kekuatan lagi sangat kokoh"

- QS. al-Zukhrūf: 32

${ }^{11}$ Sikap mental yang dermawan, sederhana tidak terbuai dengan harta dunia dan selalu berharap akan kebahagian di akherat kelak, "berpaling dari sesuatu yang dibenci Allah pada yang disukaiNya (Al Ghazali) 


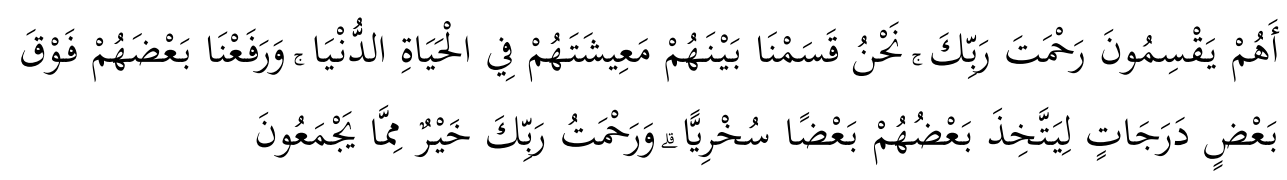

"Apakah mereka yang membagi-bagi rahmat Tuhanmu? Kami telah menentukan antara mereka penghidupan mereka dalam kehidupan dunia, dan kami telah meninggikan sebahagian mereka atas sebagian yang lain beberapa derajat, agar sebagian mereka dapat mempergunakan sebagian yang lain. Dan rahmat Tuhanmu lebih baik dari apa yang mereka kumpulkan."

Ayat ayat tersebut perlu dipahami secara sempurna, sehingga makna zuhud tidak dipahami sebagai cara mengurangi usaha untuk kaya, tapi membatasi diri dari ambisi duniawi. Allah akan berikan rezeki kepadanya sesuai kehendak-Nya, untuk kemudian semakin memuliakannya dengan rezeki tersebut.

M. Quraish shihab pun dalam menafsirkan ayat-ayat di atas dengan memberi kesimpulan bahwa kemakmuran bumi dan usaha melaksanakan fungsi kekhaliifahan bahkan beribadah secara baik, apalagi meraih kejayaan tidak dapat terlaksana tanpa harta benda dan kesucian jiwa. Dengan kata lain unsur materi harus berdampingan dengan unsur ruhani. ${ }^{12}$

\section{Kesejahteraan Sosial Umat menurut M. Quraish Shihab}

Melalui karyanya Tafsir Al Misbah yang lekat dengan ciri penafsiran analisis, rasioanal dan kontekstual, M. Quraish Shihab ${ }^{13}$ menuangkan banyak buah pemikirannya teruama dalam konsepsi bermuamalah. Ciri khas Tafsir tersebut yang seacara konsisten memberikan pemakanaan pada setiap ayat dengan teliti. Ditambah aspek lokalitas pada tafsirnya yang menjadikan Tafsir al-Misbah dapat diterima di Nusantara karena dalam pemaknaanya pula yang mampu menjangkau problematika masyarakat di zamannya.

Kesejahteraan berasal dari kata sejahtera yang berarti aman, sentosa, makmur, selamat (terlepas) dari segala macam gangguan, kesukaran,

${ }^{12}$ M. Quraish Shihab, Berbisnis dengan Allah (Tanggerang, Lentera Hati, 2008), 8.

${ }^{13}$ M. Quraish Shihab dilahirkan pada 16 Februari, di Kabupaten Dendeng Rampang, Sulawesi Selatan, yang berjarak kurang lebih 190 km dari kota Kota Ujung Padang. Nama Shihab merupakan nama yang digunakan dalam keluarga besarnya, sebagaimana digunakan dalam Wilayah Timur. Ia merupakan seseorang yang dibesarkan dalam lingkungan yang taat agama. Sejak umur sembilan tahun Quraish sudah terbiasa mengikuti ayahnya ketika mengajar. Sosok ayahnya, Abdurrahman Shihab, merupakan seseorang yang membentuk kepribadian Quraish Shihab. Ia menamatkan pendidikan di Jam'iyyat al-Khair di Jakarta, sebuah lembaga pendidikan Islam tertua di Indonesia. Ayanya seorang Guru besar di bidang Tafsir dan pernah menjabat sebagai Rektor IAIN Alaudin Ujung Padang, dan juga sebagai pendiri Universitas Muslim Indonesia (UMI) Ujung Padang. Lihat Lufaefi, Tafsir AlMishbah: Tekstualitas, Rasionalitas Dan Lokalitas Tafsir Nusantara, Substantia Volume 21 No 1 (April 2019): 30. 
keselamatan, kesenangan hidup, kemakmuran. Keadaan sejahtera itu juga digambarkan dalam UU NO. 6 tahun 1974 yaitu suatu tata kehidupan dan penghidupan sosial material maupun spiritual yang diliputi oleh rasa keselamatan, kesusilaan dan ketenteraman lahir dan batin. ${ }^{14}$

Dalam Mu'jam Muștalahăt al-'Ulüm al-Ijtima'iyyah, kesejahteraan disebut dengan kata 'al-rifăhiyyah' yang memiliki arti kondisi yang menghendaki terpenuhinya kebut uhan dasar bagi individu atau kelompok baik berupa kebutuhan pangan, pendidikan, kesehatan sedangkan lawan dari kesejahteraan adalam kesedihan (bencana) kehidupan. Padanan kata yang lain ialah 'al-salām' diambil dari akar kata salima (سلم) yang pada mulanya berarti selamat dan bebas dari bahaya. Kemudian berkembang dan menghasilkan artiarti lain, seperti memberi, menerima, patuh, tunduk, berdamai, tenteram, tidak cacat, dan ucapan selamat. Selain itu, muncul istilah 'yusr' adalah bentuk masdar dari kata yasira-yaisiru-yusran yang menunjukkan arti membuka dan meringankan sesuatu. Dari arti ini lahir beberapa istilah yang masing-masing membawa perkembangan makna, seperti kata 'yusra' dengan arti antonim sulit atau kesulitan dan kata 'yasär' yang berarti orang kaya karena kekayaan memberikan kelapangan kepada pemiliknya. ${ }^{15}$

Sosial berasal dari "Socius" yang berarti kawan, teman, dan kerja sama. Kata Sosial merupakan segala perilaku manusia yang menggambarkan hubungan non-individualis. Istilah tersebut sering disandingkan dengan cabang kehidupan manusia dan masyarakat di manapun. Pengertian sosial ini merujuk pada hubungan-hubungan manusia dalam kemasyarakatan, hubungan antar manusia, hubungan manusia dengan kelompok serta hubungan manusia dengan organisasi untuk mengembangkan dirinya ${ }^{16}$.

Dalam kamus al-Munawwir, kata sosial diistilahkan dengan kata اجنماعي yang berakar dari huruf jim-mïm-'ayn, yang menunjuk pada arti denotatif berkumpulnya sesuatu atau bisa berarti berkumpulnya sesuatu sehingga berdekatan satu sama lain. Adapun dalam Kamus Besar Bahasa Indonesia (KBBI), ditemukan bahwa kata sosial memiliki dua arti yaitu berkenaan dengan masyarakat dan suka memperhatikan kepentingan umum. ${ }^{17}$ Sekilas saja dari istilah yang diambil dari dua sumber diatas, bisa kita pahami bahwa bersosial adalah ciri seorang manusia. Pada hakikatnya manusia adalah mahluk sosial yang butuh terhadap sesamanya.

14 Widia Amelia, “Kesejahteraan Sosial Dalam Perspektif Al-Qur'an (Suatu Analisis Tafsir Tahlili terhadap QS Taha/20:117-119)," (Skripsi, UIN Alauddin Makassar, 2018), 13.

${ }^{15}$ Widia Amelia, “Kesejateraan sosial dalam persfektif Al Qur'an,” 23.

${ }^{16}$ Adi Fahrudin, Pengantar Kesejahteraan Sosial (Bandung: Reflika Aditama, 2012), 13.

${ }^{17}$ Widia Amelia, “Kesejateraan sosial dalam persfektif Al Qur'an,” 24. 
Kemudian apabila kedua kata tersebut disandingan akan membentuk istilah yang mempunyai pengertian tersendiri. Kesejahteraan sosial merupakan suatu kondisi kehidupan individu dan masyarakat yang sesuai dengan standar kelayakan hidup yang dipersepsi masyarakat. Namun tingkat kelayakan hidup tersebut dipahami relatif berbeda oleh manusia dalam berbagai kalangan dan latar belakang budaya mengingat tingkat kelayakan tersebut ditentukan oleh persepsi normatif suatu masyarakat terhadap kondisi sosial, material dan psikologis tertentu. Dalam UU Nomor 6 Tahun 2009 dijelaskan bahwa kesejahteraan sosial ialah kondisi terpenuhinya kebutuhan material, spiritual, dan sosial warga negara dapat hidup layak dan mampu mengembangkan diri, sehingga dapat melaksanakan fungsi sosialnya. Kesejahteraan sosial dalam konteks budaya dapat diartikan sebagai kondisi terpenuhinya kebutuhan-kebutuhan seseorang sesuai dengan standar yang berlaku di lingkungannya. Kesejahteraan sosial dengan demikian merupakan kondisi terpenuhinya kebutuhan-kebutuhan pokok seseorang sehingga orang tersebut dapat menjalankan fungsi sosialnya dengan normal di tengah masyarakat.

Sedangkan dalam al-Qur'an, masyarakat yang sejahtera dinamakan 'al-muflihün', yang secara harfiah berarti orang-orang yang beruntung. Indikator masyarakat sejahtera (al-muflihūn), yaitu:

"mereka yang beriman kepada yang gaib, melaksanakan salat, dan menginfakkan sebagian rezeki yang Kami berikan kepada mereka, dan mereka beriman kepada (al-Qur'an) yang diturunkan kepadamu (Muhammad) dan (kitab-kitab) yang diturunkan sebelum engkau, dan mereka yakin adanya akhirat. Merekalah yang mendapat petunjuk dari Tuhannya, dan mereka itulah orang-orang yang beruntung (meraih kesejahteraan dunia dan akhirat)" (QS. al-Baqarah/2:4-5).

Quraish shihab dalam membahas makna kata tersebut menyebutkan bahwa Al Mufilhun (orang orang yang beruntung) sebagai manifestasi dari keberhasilan usaha manusia menuju derajat takwa. Sebagai bukti orang orang al-mufliḥun sebagai aspek kesejahteraan individu yang memilki dua macam pencapaian yakni mendapatkan dua macam hidayah.

Hidayah pertama menjadikan mereka termasuk golongan orang bertakwa dengan kokohnya kesucian jiwa mereka memperoleh kebenaran dan hidayah kedua melebihi hidayah yang pertama sehingga mampu menangkap keyakinan pada yang Ghaib. ${ }^{18}$

Quraish Shihab juga memberikan pemahaman terhadap kesejahteraan yang dimaksud melalui konsepsi tentang surga, yang diharapkan menjadi arah pengabdian anak cucu Adam dan Hawa, sehingga bayang-bayang surga itu

${ }^{18}$ M Quraish Shihab, Tafsir Al-Mishbah: Pesan, Kesan dan Keserasian al-Qur'an (Tanggerang: Lentera Hati, 2000), 94. 
diwujudkannya di bumi serta kelak dihuninya di akhirat. Karena masyarakat yang mewujudkan bayang-bayang surga itu adalah masyarakat yang berkesejahteraan.

Secara spesifik, Quraish Shihab memberikan indikator kesejahteraan sosial dari penafsirannya terhadap QS. Tāhā ayat 117-119,

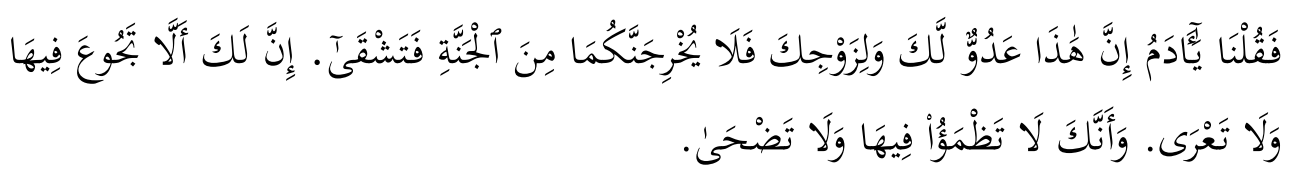

''Kemudian kami berfirman,'Wahai Adam! Sungguh ini (Iblis) musuh bagimu dan bagi istrimu, maka sekali-kali jangan sampai dia mengeluarkan kamu berdua dari surga, nanti kamu celaka. Sungguh ada (jaminan) untukmu di sana, engkau tidak kelaparan dan tidak akan telanjang. Dan sungguh di sana engkau tidak akan merasa dahaga dan tidak akan di timpa panas matahari'"

Dalam menjelaskan ayat ini, Quraish Shihab menyebutkan tiga hal yang menjadi tolok ukur yakni, pangan, sandang dan papan yang diistilahkan dengan tidak lapar, dahaga, telanjang dan kepanasan semuanya telah terpenuhi di surga. Terpenuhinya kebut uhan ini merupakan unsur pertama dan utama dari kesejahteraan sosial. Oleh karena itu, masyarakat diharapkan dapat mewujudkan bayang-bayang surga itu di dunia karena masyarakat yang mewujudkan bayang bayang surga ialah masyarakat sejahtera.

Oleh karena itu, Quraish Shihab dalam ayat tersebut memberikan isyarat kepada manusia yang hidup di dunia bahwa untuk mendapatkan kesejahteraan sosial, mereka dituntut untuk mematuhi perintah Allah Swt. untuk tidak tertipu terhadap segala godaan yang dibisikkan oleh Iblis. Ini diisyaratkan ketika Adam diperingatkan bahwa Iblis ialah musuh, ia akan menghasut untuk melakukan keburukan sehingga hal itu dapat mengeluarkannya dari surga yaitu tempat di mana ia dapat hidup dalam suasana damai, harmonis, tidak terdapat suatu dosa, tidak ada pengangguran dan segala yang bersangkutan dengan kebaikan ada di sana.

Ketiga hal tersebut (sandang, pangan, dan papan) dapat dijadikan tolok ukur kesejahteraan sosial disebabkan bahwa salah satu fondasi terciptanya kesejahteraan sosial yaitu dilihat dari keadaan kehidupan unit terkecil masyarakat yakni keluarga. Dalam kehidupan keluarga, sandang, pangan dan papan merupakan kebutuhan pokok yang harus ada, demi menciptakan keluarga yang berkualitas yaitu keluarga yang sejahtera, sehat, maju, mandiri, harmonis dan sebagainya. Karena jika ketiga tersebut tidak ada, maka akan terpengaruh dalam kehidupan keluarga, utamanya masalah kejiwaan setiap individu keluarga sehingga meluas kepada keadaan masyarakat. 
Dengan demikian, kesejahteraan sosial memiliki beberapa makna yang relatif berbeda, meskipun substansinya tetap sama. Kesejaheraan sosial pada intinya mencakup tiga aspek, yaitu: pertama, kondisi kehidupan atau keadaan sejahtera, yakni terpenuhinya kebutuhan jasmaniyah, rohaniyah dan sosial; kedua, Konstitusi, bidang kegiatan yang melibatkan lembaga kesejahteraan sosial dan berbagai profesi kemanusiaan yang menyelenggarakan usaha kesejahteraan sosial dan pelayanan sosial; ketiga, aktivitas, yakni suatu kegiatan atau usaha yang terorganisir untuk mencapai kondisi sejahtera. ${ }^{19}$

Sebagai sebuah cita-cita yang luhur dan mulia, kesejahteraan sosial tidak bisa direalisasikan dengan mudah. Namun usaha terus dilangsungkan oleh Indonesia, salah satu langkahnya adalah pembangunan nasional yang bisa disederhanakan menjadi tiga tugas utama yakni, pertumbuhan ekonomi (economy growth), perawatan masyarakat (community care) dan pengembangan manusia (human development).

Sebagaimana pendapat Gus Dur dalam bukunya "Islamku, Islam anda, Islam Kita” bahwa kepentingan mikro ekonomi Islam secara pribadi, yaitu untuk mencapai kebahagiaan dunia-akhirat, lalu sama posisinya dengan dibangunnya ekonomi makro yang mementingkan keadilan dan kemakmuran seluruh bangsa. ${ }^{20}$ Selaras dengan pemberdayaan masyarakat Islam yang menjadi mayoritas agar sadar dalam menyikapi penurunan ekonomi yang terjadi yang berakibat pada tersendatnya kemajuan peradaban. Kedaulatan bangsa sangat ditentukan oleh kedaulatan ekonominya, dan kedaulatan ekonomi sangat ditentukan jiwa bisnis masyarakatnya.

\section{Bisnis Sebagai Gerakan Dakwah}

Berdakwah tidak selalu lewat wahana lisan, ceramah, khotbah ataupun pidato di atas mimbar. Namun ada yang tidak kalah efektif yaitu bi al-ḥāl (perbuatan). Strategi dakwah bi al-ḥal tentu dilakukan dengan memperlihatkan wajah Islam yang lebih aplikatif, operasional dan pekerjaanpekerjaan berguna yang layak menjadi teladan bagi sesama. Dakwah bỉ al-ḥāl tentunya juga didasarkan pada konsep, nilai dan norma yang jelas termasuk dalam kegiatan muamalah seperti dunia bisnis kegiatan sosial, budaya pendidikan dan lainnya.

Dakwah berasal dari bahasa Arab ' $D a$ ' $\vec{a}$ yang berarti mengajak. Sebagai contoh, seorang pendakwah memerintahkan untuk tidak membuang sampah sembarangan, sedangkan dirinya sendiri berpangku tangan melihat

${ }^{19}$ Edi Suharto, Membangun Masyarakat Memberdayakan Rakyat: kajian Strategis Pembangunan Kesejahteraan Sosial dan Pekerjaan Sosial (Bandung: Reflika Aditama, 2009), 2.

${ }^{20}$ Abdurrahman Wahid, Islamku Islam Anda Islam Kita (Agama Masyarakat Negara Demokrasi)" (Jakarta: Anict HT, 2011), 178. 
kumuhnya lingkungan sekitar. Hal demikian yang justru bukan esensi dalam berdakwah, yaitu hanya memerintah tanpa cermin diri.

Maka dari itu, Nabi Saw. memberi teladan kepada umatnya untuk tidak memerintahkan berperang melainkan dirinya sendiri ikut bahkan memimpin peperangan, tidak memerintahkan ibadah melainkan dirinya adalah ahli ibadah, tidak memerintah menjaga kebersihan dan keindahan melainkan dirinya sendiri adalah seorang yang paling bersih dan indah. Demikian pula dalam dunia bisnis sebagai saudagar sukses, jujur dan paling dipercaya.

Gambaran di atas menjadi motivasi umat untuk berbisnis tanpa adanya anggapan miring terhadapnya namun justru menjadikan bisnis sebagai sarana dakwah Islam. Dengan demikian spirit umat Islam, etos kerja demikian akan menjadi bibit kemajuan perekonomian dan sebagai buahnya adalah kesejahteraan yang diharapkan. Berbisnis yang Islami tentu mempunyai banyak prinsip, itu semua bisa dilihat pada diri Rasul. Dalam berbisnois, Rasulullah Saw. selalu berpegang pada beberapa hal, di antaranya: kejujuran, amanah, tepat menimbang barang dagangan, menjauhi Gharārt sesuatu yang belum diketahui kebenarannya, tidak melakukan praktik penimbunan barang (ihtikār), tidak melakukan al-ghab (penipuan) dan tadlis (penipuan dengan menyembunyikan kecacatan). ${ }^{21}$

Lebih Juh lagi, dalam berniaga Rasulullah Saw. mendeskripsikan barang dagangannya kepada konsumen, tanpa ada yang disembunyikan. Jika barang tersebut memiliki kecacatan, maka Rasul akan berterus terang, begitupun sebaliknya. Sehingga dalam praktiknya Rasul menjadi saudagar sejak kecil dan bertahan sampai dewasa, disukai dan dipercaya konsumennya. Diriwayatkan 'Abdullāh bin Mas'ūd bahwa Nabi Saw. bersabda: "janganlah kau membeli ikan dalam air karena di dalamnya terkandung unsur penipuan". Dari 'Abdullāh bin 'Umar, Nabi Saw. bersabda: "berilah upah pekerja sebelum kering keringatnya". Dan masih banyak lagi pesan Rasul dalam bermuamalah.

Secara garis besar, bisnis yang selaras dengan Islam harus dibangun dengan beberapa tujuan, antara lain: pertama, target hasil profit (materi) dan benefit (non materi). Tujuan dari berbisnis tidak hanya mencari keuntungan materi setinggi tingginya, tetapi juga herus memiliki manfaat (benefit) non materi kepada pebisnis maupun kehidupan sosial dan lingkungan masyarakat. Materi dan kemanfaatan harus menunjang perjalanan bisnis menuju kesejahteraan. Karena dalam Islam, kemanfaatan yang dimaksud tidak semata hanya kebendaan, namun mengandung nilai nilai yang berorientasi pada kebaikan. Salah satu bentuknya adalah nilai kemanusiaan dengan

${ }^{21}$ Muhamad Saifullah, "Etika bisnis Islami dalam Praktek Bisnis Rosulullah" Walisongo, Vol. 19 no. 1 (Mei 2011): 146. 
menciptakan lapangan kerja, sedekah, dan terciptanya hubungan persaudaraan bukan sekedar hubungan profesional-fungsional. ${ }^{22}$

Kedua, Pertumbuhan. Upaya memenuhi kebutuhan hidup dengan mencari keuntungan biasanya dijadikan landasan utama dalam berbisnis. Melalui bisnis pula manusia berupaya mempertahakan keberlangsungan hidupnya. Maka dalam memaknai tujuan berbisnis hendaknya memperhatikan pegaruhnya terhadap pert umbuhan di masyarakat. Jika keunt ungan materi dan keuntungan non-materi telah diraih, perusahaan harus berupaya menjaga pertumbuhan agar selalu meningkat. Upaya peningkatan ini juga harus selalu dalam batasan syariah, bukan menghalalkan segala cara. ${ }^{23}$ Aspek lain yang menjadi perhatian dalam pertumbuhan bisnis Islam adalah ketahanan bisnis tersebut sebagai suatu entitas, kemudian pertumbuhan ekonomi umat dan pertumbuhan sosial. Artinya, luaran dari terciptanya pertumbuhan bisnis haruslah melahirkan kesejahteraan dalam tercapainya standar kehidupan pokok seperti sandang, perumahan, pangan, kesehatan dan relasi relasi sosial yang harmonis dengan lingkungannya.

Ketiga, keberkahan. Segala bentuk perbuatan tergantung pada apa yang diniatkan. Maka layaknya, sebagai pebisnis Muslim harus menggantungkan tujuan pada kehendak Allah Swt. Karena dengan adanya tujuan mulia tersebut akan meningkatkan etos kerja dan motivasi berwirausaha dalam rangka menyejahterakan masyarakat khususnya umat Muslim. Semua tujuan yang telah tercapai tidak akan berarti apa-apa jika tidak ada keberkahan di dalamnya. Maka bisnis dalam Islam menempatkan berkah sebagai tujuan inti, karena sebagai bentuk dari diterimanya segala aktivitas manusia. Keberkahan ini menjadi bukti bahwa bisnis yang dilakukan oleh pengusaha Muslim telah mendapat kehendak dari Allah Swt., dan bernilai ibadah. ${ }^{24}$

Selanjutnya Quraish Shihab menambahkan, bahwa bisnis islami dalam oprasioanlanya haruslah berpijak pada dua area: pertama, prinsip-prinsip dasar yang ditetapkan oleh al-Qur'an dan Sunnah, dan ini bersifat langgeng abadi tidak mengalami perubahan. Kedua, perkembangan positif masyarakat, ilmu pengetahuan dan teknologi, di mana terbuka lapangan yang luas untuk menampung yang baru lagi baik dari hasil pemikiran dan budi daya manusia yang berarti bersifat sementara karena bila ada yang lebih baik ditemukan, maka harus menggantikan posisi yang lama yang tidak sebaik itu. ${ }^{25}$

${ }^{22}$ Muhamamad Ardi, “Etika Bisnis dalam Ekonomi Islam”, 40.

${ }^{23}$ Akhmad Nur Zaroni, “ Motivasi Keagamaan Dalam Bisnis (Studi Pengusaha Muslim Toko Group Jawa Indah Samarinda,” Al-Tijary, Vol. 3, No. 1 (Desember 2017): 35.

${ }^{24}$ Akhmad Nur Zaroni, "Motivasi Keagamaan Dalam Bisnis (Studi Pengusaha Muslim Toko Group Jawa Indah Samarinda)," 37.

${ }^{25}$ M. Quraish Shihab, Berbisnis dengan Allah (Tanggerang: Lentera Hati, 2008), 10. 
Lebih spesifik, Quraish Shihab memberikan rambu-rambu sebagai pondasi berbisnis dalam Islam yang berlandaskan pada tauhid, kemudian di sekelilingnya banyak terikat ketentuan yang mengikutinya. Pertama, Tauhid. Melahirkan keyakinan bahwa segala sesuatu itu datang dan bersumber dari Allah Swt. yang satu dann pasti berakhir pula padanya. Dialah yang berkuasa mutlak terhadap segala sesuatu, termasuk kepemilikan harta dan juga kewenangan pengelolaan dan pemanfaatannya.

Kedua, kemaslahatan umat manusia. Dalam setiap produk kebijakan ataupun amaliah apapun yang menyangkut hidup manusia haruslah berpedoman pada keadilan dan kemaslahatan umat. Karena zaman yang terus berputar maka konsepsi kemaslahatan pun harus terus dinamis. Boleh jadi ketetapan yang tidaj relevan dengan kemaslahatan akan digunakan di zaman lain yang membutuhkan, karena pada dasarnya al-Qur'an harus selalu maslahat di setiap zaman.

Ketiga, kesatuan kemanusiaan. Pada prinsipnya seorang pebisnis Islam harus menyadari keterikatan dan keterkaitan dirinya dengan sesama. Oleh karena itu, segala bentuk eksploitasi dan kecurangan yang mengakibatkan kerugian harus dihindari. Kesatuan manusia akan mendorong pemikiran agar mempertimbangkan kepentingan umat manusia seluruhnya, bukan hanya untuk generasinya tapi juga generasi selanjutnya.

Keempat, keyakinan akan kesatuan dunia dan akhirat. Hal ini yang menjadi motivsi besar bagi pebisnis Islam, karena akan mendorongya memiliki visi yang jauh kedepan bukan hanya berorientasi pada keuntungan duniawi tetapi juga kebahgiannya di akhirat. Dari sini pula al-Qur'an mengingatkan bahwa sukses yang diraih bagi mereka yang berpandangan pendek, bisa melahirkan penyesalan dan kelak mereka merugi dan dikecam. ${ }^{26}$

Melalui tujuan dan prinsip dasar yang disajikan tersebut dapat penulis simpulkan secara garis besar, bahwa tiga aspek yang harus terpenuhi bagi setiap pebisnis islami melingkupi kepercayaan atau kondisi hati pebisnis, Moralitas dan praktek bisnis dan Pemberdayaan keuntungan bisnis.

\section{Relasi Bisnis Islami dengan Kesejahteraan Sosial di Indonesia dalam Tafsir al-Misbah}

Ditinjau dari aspek sejarah Islam di Indonesia, para pedagang muslim mempunyai peranan penting bagi masuknya Islam ke tanah air. Sebagaimana diketahui bersama bahwa ada dua teori yang menyatakan bahwa Islam masuk lewat para saudagar dari Gujarat dan dari Persia. Teori Gujarat yang dikemukakan oleh S. Hurgronje dan Pijnapel ini menyatakan Islam masuk ke Nusantara pada sekitar abad ke-13 lewat pedagang dari Gujarat, India dan

${ }^{26}$ M. Quraish Shihab, Berbisnis dengan Allah, 13. 
mendarat di Malaka. Kemudian Amir Husen berpendapat Islam masuk dibawa pedagang dari Persia pada abad ke-13.

Maka tidak heran jika para pendakwah Islam biasa memiliki profesi ganda, selain sebagai juru dakwah bi al-lisān, juga juru dakwah bi al-ḥal melalui bisnis. Karena itu akan banyak dijumpai para santri dengan semangat yang tinggi terhadap bisnis. Sentra bisnis yang di dalamnya terdapat santri pun fokus pada bidang perdagangan seperti, Tasikmalaya, Pekalongan, Yogyakarata dan lainnya.

Namun seiring zaman berlalu etos para saudagar dimungkinkan akan berkurang juga, terutama jika melihat kondisi merosotnya motivasi bisnis umat muslim. Hal tersebut dapat dilihat dari banyaknya umat muslim yang berada di garis kemiskinan, terutama karena sebagai umat mayoritas di Indonesia. Melalui pembangunan kondisi yang stabil di masyarakat akan memberikan wahana yang luas kepada masyarakat muslim di Indonesia dalam usahanya membangun kehidupan yang sejahtera. Oleh karena itu, persoalan kemiskinan yang melilit umat Islam disebabkan adanya pemahaman nilai yang keliru, diperparah dengan buruknya tatanan ekonomi lokal dan global serta ketidakmampuan negara menciptakan lapangan kerja. Menurut K.H Hasyim Muzaldi sebagaimana yang dikutip oleh Azrul Tanjung mengatakan bahwa salah satu jalan yang bisa ditempuh untuk menggerakan laju ekonomi nasional sekaligus meningkatkan kesejahteraan rakyat, dengan berpijak pada tiga pilar, pertama, memberdayakan ekonomi di pondok pesantren melalui pengembangan koperasi UKM dalam sektor riil. Kedua, pemberdayaan ekonomi masyarakat pedasaan dengan menitikberatkan pembangunan berbasis sektor pertanian, ketahanan pangan dan pengembangan agrobisnis, kesejahteraan petani, agraria dan lainya. Ketiga, pemberdayaan ekonomi masyarakat perkotaan melalui pengembangan lembaga keuangan mikro syari'ah dan lembaga Amil Zakat Infak Shodaqah (LAZIS) melalui penyaluran zakat dan infak yang proporsional, Baitul Mal Wa Ta'mil (BMT), Bank Umum Syariah dan lainya. ${ }^{27}$

Melihat sejarah perkembangan ekonomi Islam sendiri, Rasulullah menjadi aktor utama dan orang pertama yang memperkenalkan konsep baru di bidang keuangan negara, yaitu bayt al-māl. Semua hasil penghimpunan kekayaan negara harus dikumpulkan terlebih dahulu dan kemudian dikeuarkan sesuai dengan kebutuhan negara. ${ }^{28}$

Selain pondasi dasar tersebut, langkah Rasulullah membangun kekuatan ekonomi dengan membangun kemitraan. Sebagaimana halnya

${ }^{27}$ M Azrul Tanjung, dkk, Reinventing Budaya Bisnis, 119-120

28 Euis Amalia, Sejarah Pemikiran Ekonomi Islam, Dari masa Klasik hingga Kontemporer (Depok: Gramata Publishing, 2010), 78. 
ketika Rasul mengarahkan kaum Muhajirin dan Anshar diawal kedatangan hijrahnya untuk melakukan akad muḍ̄arabah, muzāra'ah dan masāqat satu sama lain. Melalui kemitraan tersebut meningkatkan tenaga kerja kaum muhajirin dan pemberdayaan modal kaum Anshar sehingga pertumbuhan aktivitas ekonomi semakin stabil.

Salah satu tujuan khusus perekonomian pada awal perkembangan Islam adalah investasi tabungan yang dimiliki masyarakat. Hal ini diwujudkan dalam dua cara, yaitu mengembangkan peluang investasi Islami secara legal dan mencegah kebocoran penggunaan tabungan untuk tujuan yang tidak Islami.

Quraish Shihab memberikan pandangan mengenai pengelolaan ekonomi umat dengan negara yang diberi wewenang untuk mengawasi segala sesuatu yang menyangkut kepentingan mereka, hal itu diistilahkan olehnya dengan al-amr bì alma'rüf dan al-nahy 'an al-munkar. Atas dasar prinsip ini, maka pengawasan terhadap harta benda dapat dibenarkan. Di lain sisi, perlu digarisbawahi bahwa Islam dapat membenarkan segala macam tindakan pemerintah selama tindakan tersebut menunjung "kepentingan dan kemaslahat an masyarakat umum". Hal ini dalam istilah hukum Islam, dinamai al-masăliḥ al-mursalah. ${ }^{29}$ Maka sepak terjang perekonomian negara merupakan implikasi dari keserasian dan kompetensi pemerintah dalam memberikan pengawasan dan pengaturan.

Pada awal perkembangannya, melalui berbagai cara pemerintah menyediakan fasilitas yang berorientasi investasi. Pertama, memberikan kemudahan bagi produsen untuk berproduksi. Kedua, memberikan keuntungan pajak terutama bagi unit produksi baru. Ketiga, meningkatkan efisiensi produksi sektor swasta dan peran serta masyarakat dalam berinvestasi. Metode lainnya untuk menyalurkan tabungan dalam kegiatan investasi adalah infaq dan wakaf, karena terdapa unsur motivasi spiritual dalam dua hal ini, kaum Muslim menunjukan ant usiasmenya untuk melakukan infaq dan wakaf. ${ }^{30}$

Dewasa ini telah banyak model kelembagaan yang berkembang dalam ajaran Islam yang berkaitan dengan pola kelembagaan usaha ini, di antaranya:

\section{Instrumen Zakat}

Zakat merupakan pranata keagamaan untuk mewujudkan keadilan sosial bagi masyarakat dengan memperhatikan masyarakat yang kurang mampu, dan hasil pengumpulan zakat merupakan sumber dana yang potensial bagi upaya mewujudkan kesejahteraan

${ }^{29}$ Muhammad Iswadi, "Pemikiran Quraish Shihab Tentang Ayat-Ayat Ekonomi" Fenomena Volume V, No. 2 (201): 250.

30 Euis Amalia, Sejarah Pemikiran Ekonomi Islam, Dari masa Klasik hingga Kontemporer, 86. 
masyarakat. Kemudian lembaga zakat merupakan sarana distribusi kekayaan di dalam ajaran Islam yang merupakan kewajiban. ${ }^{31}$

Tujuan akhir dari zakat adalah penyalurannya (distribusi) kepada sebagian masyarakat yang membutuhkannya (mustahiq) sehingga dapat memberikan distribusi pendapatan yang adil sehingga akan memberikan pengaruh pada tingkat kesejahteraan sosial. Berdasarkan tujuan tersebut, pengelolaan zakat, dari penarikan hingga penyalurannya harus dilakukan oleh sebuah institusi khusus, sehingga zakat dapat dikelola dengan baik. Pembayaran zakat secara individual tentunya akan menjadikan pola distribusi zakat tidak terkontrol dan tidak merata, serta tujuan akhir dari zakat itu akan sulit untuk dicapai.

Menurut Abū Ubayd sebagaimana yang dikutip oleh Taufik Hidayat menyatakan bahwa tujuan zakat yang terpenting adalah memenuhi kebutuhan-kebutuhan dasar, berapapun besarnya, serta bagaimana menyelamatkan orang-orang dari bahaya kelaparan. Oleh sebab itu, pendekatan yang dilakukan oleh Abū Ubayd ini mengindikasikan bahwa ada tiga kelompok sosio-ekonomi yang terkait dengan status zakat, yaitu: 1) Kalangan kaya yang terkena wajib zakat; 2) Kalangan menengah yang tidak terkena wajib zakat, tapi juga tidak berhak menerima zakat; 3) Kalangan penerima zakat. ${ }^{32}$

Adanya pemerataan harta lewat zakat dan pengelolaan yang tepat dan efektif diharapkan bisa menciptakan kesejahteraan yang dinanti. Atas dasar tersebut keberadaan Badan Amil Zakat (BAZ) dan lembaga lembaga partikulasi semacam LAZISMuh, LAZIS-NU, DD, Rumah Zakat dapat diberdayakan sebagai suatu upaya. Harakah zakat adalah gerakan kemanusiaan dan universalitas yang menitikberatkan pada kesejahteraan kolektif dan dengan kondisi tersebut berimplikasi pada peningkatan kualitas umat manusia.

\section{Asuransi Syariah}

Pengertian Asuransi Syariah berdasarkan Dewan Syariah Nasional (DSN) dan Majelis Ulama Indonesia (MUI) adalah sebuah usaha saling melindungi dan tolong menolong di antara sejumlah orang melalui investasi dalam bentuk aset dan/atau tabarru' yang

${ }^{31}$ Mujahidin, "Tinjauan Terhadap Pendistribusian Zakat Profesi dalam Peningkatan Kesejahteraan Masyarakat ( Studi pada BAZNAS Kab. Maros)," Al-Tijary Jurnal Ekonomi dan bisnis islam Vol. 4, No. 2 (Juni 2019): 164.

32 Taufik Hidayat, “Abu Ubaid sebagai Fuqaha' dan Ekonom: Critical Reading terhadap Corak Pemikiran dan Konsepsi Ekonomi Ibn Ubaid”: 11. 
memberikan pola pengembalian untuk menghadapi risiko tertentu melalui akad yang sesuai dengan syariah. ${ }^{33}$

Prinsip utama asuransi syariah adalah kejelasan dana, tidak mengandung unsur riba, judi atau bunga. Melihat potensi umat Indonesia, prospek asuransi syariah sangat menjanjikan. Badan Asosiasi Syariah di Indonesia meyebutkan, tingkat pertumbuhan asuransi selama 5 tahun terakhir (2010-2015), 40\% untuk syariah sedangkan konvensional hanya $22,7 \%{ }^{34}$

Bersandar pada konsep yang ditawarkan Quraish Shihab sebagaimana yang dikutip oleh Muhammad Iswadi, dalam hal tata kelola keuangan negara, khususnya modal Modal tidak boleh diabaikan, manusia berkewajiban menggunakannya dengan baik, agar ia terus produktif dan tidak habis digunakan. Modal juga tidak boleh menghasilkan dari dirinya sendiri, tetapi harus dengan usaha manusia. Ini salah satu sebab mengapa membungakan uang, dalam bentuk riba dan perjudian, dilarang oleh al-Quran. Salah satu hikmah pelarangan riba, serta pengenaan zakat sebesar 2,5\% terhadap uang (walau tidak diperdagangkan) adalah untuk mendorong aktivitas ekonomi, perputaran dana, serta sekaligus mengurangi spekulasi serta penimbunan. Dari sini dapat ditangkap kesan bahwa menurut Quraish Shihab harta atau uang tidak boleh nganggur dan pengembangannya sebaiknya di sektor riil bukan di sektor keuangan, seperti murabāhah, mud̄àrabah, atau mushārakah. Karena uang dijadikan Allah untuk sarana kehidupan dan pemenuhan kebutuhan manusia. ${ }^{35}$

Model asuransi syariah bisa menjadi langkah pembangunan ekonomi nasional yang diawasi secara masif oleh pemerintah. Sebagaimana tertuang dalam UU No. 40 tahun 2014, Pasal 57 Ayat (2) "Kebijakan umum dalam rangka pengembangan pemanfaatan asuransi dan reasuransi untuk mendukung perekonomian nasional meliputi hal kepemilikan asing atas Perusahaan Perasuransian, peningkatan kapasitas asuransi, asuransi syariah, reasuransi, dan reasuransi syariah dalam negeri, serta pemberian fasilitas fiskal kepada perseorangan, rumah tangga, dan/atau usaha mikro, kecil, dan menengah". Dengan berkembangnya asuransi berbasis syariah, pemerataan dana umat dan pemanfaatannya untuk pembangunan ekonomi umat selaras dengan konsep Quraish Shihab yang perhatian terhadap harta umat serta pemanfaatannya.

${ }^{33}$ Herry Ramadhani, "Prospek dan Tantangan Perkembangan Asuransi Syariah di Indonesia," AL-TIJARY Vol. 01, No. 01 (Desember 2015): 59.

${ }^{34}$ Tanjung, M Azrul dkk, Reinventing Budaya Bisnis, 126

${ }^{35}$ Muhammad Iswadi, "Pemikiran Quraish Shihab Tentang Ayat-Ayat Ekonomi," Fenomena Volume V, No. 2 (201): 251. 
Produk bisnis Islam ini salah satu yang sedang berkembang pesat, pada akhirnya sistem ekonomi syariah yang akan membawa dampak lahirnya para pelaku bisnis yang bukan hanya berjiwa usaha namun juga Islami.

\section{Pesantren}

Pesantren sebagai lembaga pendidikan non-formal menjadi salah satu wadah membentuk karakter dan membangun mental dan wawasan, maka perlu kiranya dimaksimalkan untuk menggerakan ekonomi umat. Banyak pesantren yang memiliki unit usaha sendiri di dalamnya, di mana perputaran uang berjalan hingga milyaran rupiah. Seperti pesantren Gontor, Sidogiri Pasuruan dan Darunnajah Jakarta. ${ }^{36}$

Sebagai rumah sekaligus sebagai sekolah, pesantren mempunyai peranan sangat penting dalam mempersiapkan para santrinya. Atas dasar tersebut model pendidikan di pesantren telah banyak mewujud dalam aspek sosial keagamaan guna terciptanya santri yang siap mengahadapi dunianya. Sehingga kontribusinya dalam kemajuan ekonomi terlihat dalam mempersiapkan santri menjadi generasi pebisnis. Kesan kesederhanaan menjadi ciri tersendiri, namun dengan pemahaman yang utuh terhadap konsep kesederhanaan justru akan melahirkan pebisnis yang jujur, peduli dan memiliki etos kerja yang tinggi.

Pesantren merupakan wadah pembentuk generasi yang mempunyai jiwa usaha tinggi, bukan sebagai lembaga bisnis. Peran pesantren sendiri hendakanya bisa terus ditopang oleh pemerintah, karena tidak bisa diabaikan bahwa kesadaran akan pentingnya stabilitas ekonomi bisa dibangun melalui model pendidikan. Sebagaimana filosofi yang dikemukakan Abū Ubayd merupakan sebuah pendekatan yang bersifat profesional yang bersandar pada kemampuan teknis, dan tidak menyimpang dari prinsip-prinsip keadilan dan masyarakat beradab. Pandangan Abù Ubayd mengedepankan dominasi intelektualitas islami serta bersifat teologis. Ini menjadi fondasi bagi kehidupan manusia di dunia dan akhirat, baik individu maupun sosial. ${ }^{37}$

Sebenarnya masih banyak sektor lain yang apabila diperhatikan akan menjadi potensi yang besar bagi umat. Misalnya sektor wakaf, pengembangan Masjid, bayt al-māl dan lainya. Yang terpenting dalam prinsipnya menjadikan

\footnotetext{
${ }^{36}$ Tanjung, M Azrul dkk, Reinventing Budaya Bisnis, 127.

${ }^{37}$ Asra Febriani \& Jalaluddin, "Pemikiran Ekonomi Abu Ubaid Al-Baghdadi": 132.
} 
berbisnis sebagai sarana ibadah, dakwah bahkan jihad akan sangat bermanfaat khususnya bagi umat Islam sendiri.

Dengan kuatnya budaya bisnis bernuansa Islami ditunjang dengan kelembagaan dan peran serta tokoh agama dan pemerintah, diharapkan kualitas hidup yang sejahtera, terbebas dari kemiskinan sehingga hidup tentram baik lahir maupun batin.

\section{SIMPULAN}

Bisnis dalam Islam mengandung makna yang menunjukan suatu praktik bersosial lewat pemanfaatan sumber daya dan mencari keuntungan berdasarkan prinsip-prinsip yang Islami. Model bisnis Islami yang telah dicontohkan Rasul dan berkembang mengikuti arus sejarah telah mengalami transformasi yang tidak singkat. Namun, modal dalam berbisnis tidak dapat terlepas dari tiga tujuan utama, yakni: mencari keunt ungan bukan hanya profit (materi) namun juga benefit (non materi); pertumbuhan bisnis, ekonomi dan kesejahteraan umat; mencari keberkahan atau kehendak Allah Swt. semata.

Pemikiran Quraish Shihab telah memberikan rambu-rambu dalam berbisnis dengan prinsip Tauhid, kemaslahatan umat manusia, kesatuan kemanusiaan, keyakinan akan kesatuan dunia dan akhirat. Menghasilkan konsep pengelolaan harta yang baik dan harmonis pula antara pelaku bisnis dengan negara dalam menciptakan kesejahteraan.

Perhatian Islam pada setiap usaha yang mengandung manfaat sangat besar dan mendapat apresiasi tersendiri dalam kualitas spiritual seorang hamba. Ajaran Islam yang luas tidak sekedar praktik peribadatan formal, namun masuk pada setiap sendi kehidupan termasuk praktik muamalah. Hal ini membuktikan bahwa anggapan miring terhadap bisnis telah tertolak sendirinya oleh esensi bermualah dalam Islam. Dengan kesadaran umat, spirit, dan etos kerja yang telah terbangun dalam jiwa seorang Muslim diharapkan dapat andil dalam bisnis yang Islami sehingga menjadi sumbangsih upaya pengembangan ekonomi umat serta berimplikasi pada kesejahteraan sosial bagi masyarakat luas.

\section{DAFTAR PUSTAKA}

Amalia, Euis. Sejarah Pemikiran Ekonomi Islam, Dari masa Klasik Hingga Kontemporer. Depok: Gramata Publishing, 2010.

Amelia, Widia. "Kesejahteraan Sosial Dalam Perspektif Al-Qur'an (Suatu Analisis Tafsir Tahlili terhadap QS Taha/20:117-119)". Skripsi, UIN Alauddin Makassar, 2018.

Ardi, Muhamamad. "Etika Bisnis dalam Ekonomi Islam." Jurnal Syari'ah Vol. III, No. 1 (April 2015): 29-56.

Elkarimah, M. "Etos Kerja Islami dalam Mewujudkan Kesejahteraan Sosial" An-Nuha Vol. 3, no. 1 (Juni 2016): 94-108. 
Fahrudin, Adi. Pengantar Kesejahteraan Sosial. Bandung: Reflika Aditama, 2012.

Febriani, Asra \& Jalaluddin. "Pemikiran Ekonomi Abū Ubayd Al-Baghdadi (Studi Kitab Al-Amwal)" Jurispundensi Vol. IX, No. 2 (Desember 2017): 128-129.

Hidayat, Taufik. "Abū Ubayd sebagai Fuqaha' dan Ekonom: Critical Reading terhadap Corak Pemikiran dan Konsepsi Ekonomi Ibn Ubaid" AlFalah: Journal of Islamic Economics Vol. 4, No. 1 (2019).

Herry Ramadhani, "Prospek dan Tantangan Perkembangan Asuransi Syariah di Indonesia" Al-Tijary Vol. 01, No. 01 (Desember 2015): 57-66.

Iswadi, Muhammad. "Pemikiran Quraish Shihab Tentang Ayat-Ayat Ekonomi." Fenomena Volume V, No. 2 ( 2013): 241-259.

Lufaefi. "Tafsir Al-Misbah: Tekstualitas, Rasionalitas Dan Lokalitas Tafsir Nusantara.” Substantia Volume 21, No 1 (April 2019): 29-40.

Mujahidin. "Tinjauan Terhadap Pendistribusian Zakat Profesi dalam Peningkatan Kesejahteraan Masyarakat (Studi pada BAZNAS Kab. Maros)." Al-Tijary Jurnal Ekonomi dan bisnis Islam Vol. 4, No. 2 (Juni 2019): 155- 168.

Norvadewi. "Bisnis dalam Persfektif Islam (Telaah Konsep, Prinsip dan Landasan Normatif)." Al-Tijary Vol. 01, No. 01 (Desember 2015): 3345.

Saifullah, Muhamad. "Etika bisnis Islami dalam Praktik Bisnis Rasulullah." Walisongo. Vol. 19, No. 1 (Mei 2011): 127-156.

Shihab, M Quraish. Tafsir Al-Misbah: Pesan, Kesan dan Keserasian alQur'an. Tanggerang: Lentera Hati, 2000. 2008.

Suharto, Edi. Membangun Masyarakat Memberdayakan Rakyat : kajian Strategis Pembangunan Kesejahteraan Sosial dan Pekerjaan Sosial. Bandung: Reflika Aditama, 2009.

Tanjung, M Azrul dkk. Reinventing Budaya Bisnis untuk Kesejahteraan dan Kejayaan Peradaban Islam. Jakarta: Grafindo, 2014.

Wahid, Abdurrahman. Islamku Islam Anda Islam Kita (Agama Masyarakat Negara Demokrasi). Jakarta: Anict HT, 2011.

Zamroni. "Dinamika interkorelasi antara konsep Diri, Zuhud dan Motivasi berprestasi Santri". UIN Maulana Malik Ibrahim Malang, 2010.

Zaroni, Akhmad Nur. "Motivasi Keagamaan Dalam Bisnis (Studi Pengusaha Muslim Toko Group Jawa Indah Samarinda)." AL-TIJARY Vol. 3, No. 1 (Desember 2017): $29-45$. 